\title{
Plasma zinc concentration and children's infectious diseases
}

\author{
Nicoleta Negruț ${ }^{1,2^{*}}$, Lucian Negruț ${ }^{3}$ \\ From The 9th Edition of the Scientific Days of the National Institute for Infectious Diseases Prof Dr Matei Bals \\ Bucharest, Romania. 23-25 October 2013
}

\section{Background}

Zinc deficiency perturbs the immune response and generates higher susceptibility of the human body to infections.

\section{Methods}

The study's primary outcome was the plasma concentration of zinc. The colorimetric method with Br-PAPS final point (CV\% 0.98\% - 4.64\%) was used for the determination of the zinc level. Secondary outcomes were the prevalence of the acute infectious diseases in children and their relationship with plasma concentration of zinc. Data were processed using EPIINFO version 6.0.

\section{Results}

During 2009-2011, 98 healthy children, 0-3 years old, from Bihor county, Romania, were enrolled in the study. A total of 96 children recruited were available for analysis. In the study group $(\mathrm{n}=96)$ the mean plasma concentration of zinc was $15.33 \pm 1.49 \mu \mathrm{mol} / \mathrm{L}$.

Subjects with more than 3 episodes of acute respiratory infections/year had a statistically significant lower value of plasma concentration of zinc as compared to those who had less than 3 episodes/year $(14.23 \pm 0.76 \mu \mathrm{mol} / \mathrm{L}$ versus $15.89 \pm 1.46 \mu \mathrm{mol} / \mathrm{L}, \mathrm{p}<0.001$, Student's $\mathrm{t}$ test).

There are no significant differences between those who had an episode of acute diarrhea/year compared with more than 1 episode/year $(15.49 \pm 1.44 \mu \mathrm{mol} / \mathrm{L}$ versus $15.09 \pm 1.56 \mu \mathrm{mol} / \mathrm{L}, \mathrm{p}=0.480$, Student's t test).

Children with a history of parasitic infections had a mean plasma concentration of zinc similar to those without parasitic infections $(15.01 \pm 1.32 \mu \mathrm{mol} / \mathrm{L}$ versus 15.42 $\pm 1.14 \mu \mathrm{mol} / \mathrm{L}, \mathrm{p}=0.450$, Student's $\mathrm{t}$ test).

\footnotetext{
* Correspondence: negrut.mihaela@umfcluj.ro

${ }^{1}$ Third Department of Pediatrics, luliu Hațieganu University of Medicine and Pharmacy, Cluj-Napoca, Romania

Full list of author information is available at the end of the article
}

\section{Conclusion}

In our study, the children aged 0-3 years showed no zinc deficiency. Smaller plasma concentrations of zinc were associated with more than 3 episodes of acute respiratory infections/year.

\section{Authors' details}

${ }^{1}$ Third Department of Pediatrics, luliu Hațieganu University of Medicine and Pharmacy, Cluj-Napoca, Romania. ${ }^{2}$ Department of Neuroscience and Recovery, Faculty of Medicine and Pharmacy, University of Oradea, Romania. ${ }^{3}$ West University of Timişoara, Romania.

Published: 16 December 2013

\section{doi:10.1186/1471-2334-13-S1-P62}

Cite this article as: Negruț and Negruț: Plasma zinc concentration and children's infectious diseases. BMC Infectious Diseases 2013 13(Suppl 1): P62.
Submit your next manuscript to BioMed Central and take full advantage of:

- Convenient online submission

- Thorough peer review

- No space constraints or color figure charges

- Immediate publication on acceptance

- Inclusion in PubMed, CAS, Scopus and Google Scholar

- Research which is freely available for redistribution
() Biomed Central

\section{() Biomed Central}

